\title{
Kendala Pembiayaan Bank Syariah : Pendekatan Granger Causality
}

\section{Faizul Mubarok}

Universitas Islam Negeri Syarif Hidayatullah Jakarta

fayzmubarok@uinjkt.ac.id

\section{Rusdianto}

Universitas Islam Negeri Syarif Hidayatullah Jakarta rusdianto@uinjkt.ac.id

\begin{abstract}
Abstrak
Penelitian ini bertujuan untuk menguji hubungan dua atau satu arah antara pembiayaan perbankan syariah, nilai tukar, inflasi dan suku bunga di Indonesia. Alat analisis yang digunakan adalah Granger Causality. Data yang digunakan menggunakan data sekunder meliputi pembiayaan perbankan syariah, nilai tukar, inflasi dan suku bunga dari Januari 2010 hingga Desember 2017. Hasil yang diperoleh menunjukkan bahwa variabel pembiayaan dan variabel inflasi, variabel pembiayaan dan variabel suku bunga, variabel nilai tukar dan variabel inflasi, variabel nilai tukar dan variabel tingkat bunga tidak memiliki hubungan dua arah atau satu arah, sementara variabel inflasi dan variabel suku bunga memiliki hubungan satu arah, variabel pembiayaan dan variabel nilai tukar memiliki hubungan dua arah.

Kata Kunci Granger Causality, Pembiayaan, Nilai Tukar, Inflasi dan Suku Bunga
\end{abstract}

\section{PENDAHULUAN}

Praktek perbankan berdasarkan prinsip syariah semakin meningkat semenjak dikeluarkannya Undang-undang Nomor 10 tahun 1998 yang merupakan perubahan dari Undang-undang Nomor 7 tahun 1992 serta diperkuat oleh Undang-undang Nomor 21 tahun 2008 tentang Pebankan Syariah. Dengan demikian, Indonesia telah menganut Dual Banking System. Perbedaan paling mendasar antara perbankan syariah dan perbankan konvensional terletak pada bunga. Pada bank syariah tidak mengenal sistem bunga, sehingga profitnya bersumber dari bagi hasil dengan pelaku usaha yang menggunakan dana dari bank syariah serta investasi dari bank syariah sendiri (Antonio, 2001).

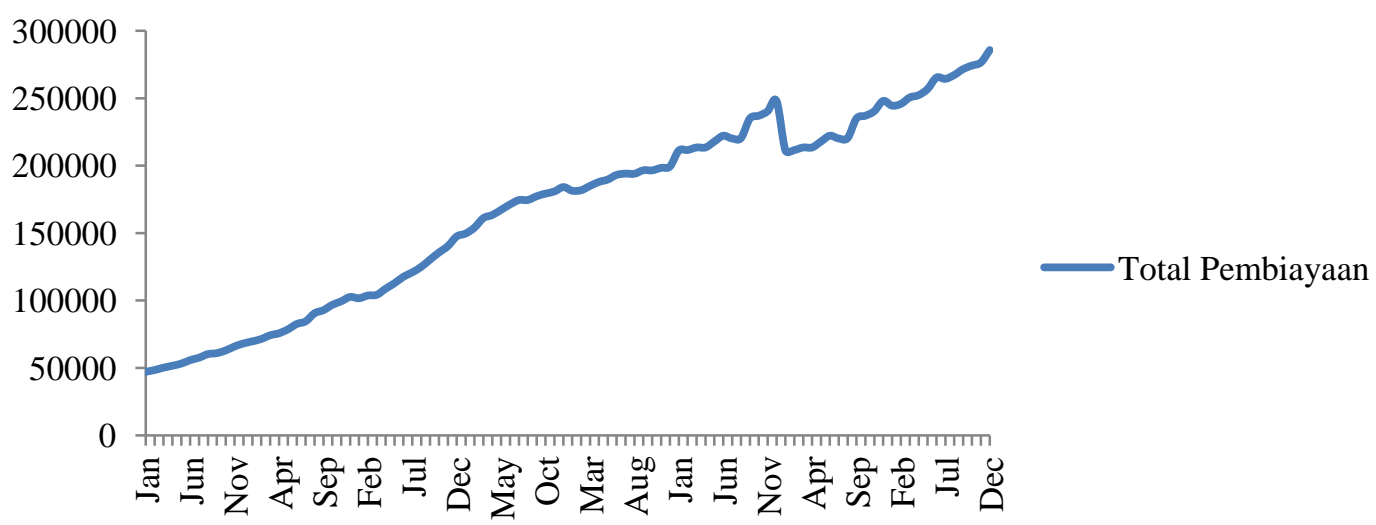

Gambar 1. Total pembiayaan perbankan syariah tahun 2015-2017 (miliar rupiah).

Sumber : Statistik Perbankan Syariah (2017) 
Dalam menjalankan fungsinya sebagai lembaga perantara, sebuah bank tentunya membutuhkan dana dalam kegiatan operasionalnya. Karena itu, setiap bank selalu berusaha untuk mendapatkan dana yang optimal dengan cost of money yang wajar. Semakin banyak dana yang dimiliki suatu bank, maka semakin besar peluang bagi bank untuk melakukan kegiatan operasionalnya dalam mencapai tujuan. Adapun peranan perbankan sebagai lembaga perantara tidak pernah luput dari masalah kredit atau pembiayaan (Ardana \& Irviani, 2017). Penyaluran kredit atau pembiayaan merupakan kegiatan dan sumber pendapatan utama suatu perbankan.

Pada gambar 1 terlihat bahwa jumlah pembiayaan yang berhasil disalurkan oleh perbankan syariah ke berbagai sektor perekonomian dari tahun 2015 sampai dengan tahun 2017 mengalami peningkatan yang sangat baik, walaupun sempat mengalami penurunan pada akhir tahun 2015. Bagi perbankan syariah, semakin besarnya jumlah pembiayaan yang berhasil disalurkan ke berbagai sektor perekonomian akan membawa konsekuensi semakin besarnya risiko yang harus ditanggung. Adapun risiko yang harus ditanggung salah satunya berasal dari faktor eksternal. Pergerakan-pergerakan faktor ekternal ini diduga memberikan pengaruh terhadap penyaluran pembiayaan yang diberikan oleh perbankan syariah.

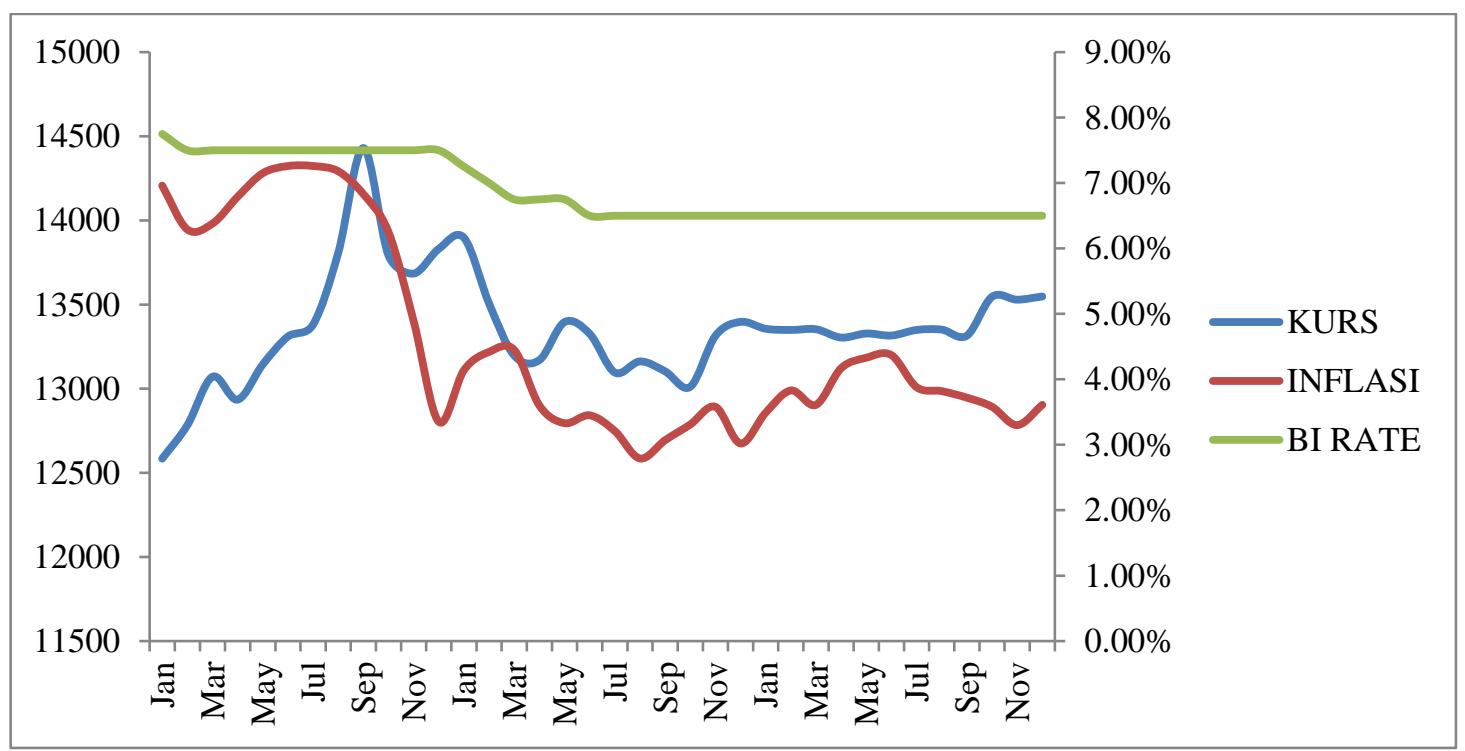

Gambar 2. Pergerakan Nilai Tukar, Inflasi dan Suku Bunga 2015-2017 Sumber : Statistik Perbankan Syariah (2017)

Faktor ekternal tersebut diantaranya nilai tukar, inflasi dan suku bunga. Forbes et al. (2018) menyatakan bahwa tantangan utama untuk kebijakan moneter adalah memprediksi bagaimana pergerakan nilai tukar akan mempengaruhi inflasi. Lebih lanjut lagi menyatakan model perekonomian terbuka menunjukkan bahwa hubungan antara nilai tukar dan harga tergantung pada goncangan yang menyebabkan pergerakan nilai tukar (Forbes et al., 2018). Pergerakan suku bunga yang berfluktuatif akan berakibat pada permodalan bank yang pada akhirnya akan berdampak pada pembiayaan (Naufal et al., 2017). Inflasi juga merupakan salah satu faktor penentu pertumbuhan ekonomi di Indonesia. Dalam jangka pendek inflasi dapat menguntungkan bagi produsen karena akan meningkatkan tingkat harga sehingga produsen akan meningkatkan jumlah produksinya (Ichsan \& Akhiroh, 2018). Kebijakan moneter dalam merespon kenaikan tingkat inflasi dilakukan dengan mengeluarkan kebijakan moneter yang bersifat kontraktif, seperti menaikkan tingkat suku bunga (SBI). Pengembangan perbankan syariah dengan melakukan pembiayaan, sebenarnya akan meningkatkan efisiensi pada ekonomi makro 
(Gheeraerta \& Weill, 2015). Disamping itu, pertumbuhan pembiayaan sektoral perbankan syariah meningkatkan eksposur risiko kredit lebih besar dari pada perbankan konvensional (Alandejania \& Asutay, 2017).

Pada gambar 2 di atas menjelaskan mengenai pergerakan kondisi makroekonomi meliputi nilai tukar, inflasi dan suku bunga. Terlihat dari pergerakan tersebut nilai tukar dan inflasi cenderung mengalami pergerakan yang berfluktuatif. Nilai tukar sepanjang pengamatan memiliki rata-rata sebesar Rp. 13.360,- dengan titik tertinggi berada pada September 2015 sejumlah Rp. 14.430,- dan titik terendah berada pada Januari 2015 sejumlah Rp. 12.584,-. Inflasi memiliki rata-rata 5 persen sepanjang pengamatan dengan titik tertinggi berada pada Mei-Juni 2015 sejumlah 7,26 persen dan titik terendah berada pada Desember 2016 sejumlah 3,02 persen. Sedangkan tingkat suku bunga cenderung mengalami penurunan dan tetap dari pengamatan yang dilihat dari 7,75 persen pada awal tahun 2015 menjadi 6,5 persen pada akhir tahun 2017.

Berdasarkan penjelasan di atas, penelitian lebih lanjut meneliti mengenai pengaruh dan hubungan dari kendala-kendala ekonomi makro yang dialami dalam melakukan pembiayaan.

\section{LANDASAN TEORI}

\section{Pembiayaan}

Pembiayaan yang dilakukan perbankan syariah, yaitu pendanaan yang diberikan untuk mendukung investasi yang telah direncanakan, baik dilakukan sendiri maupun bersama-sama (Muhammad, 2005). Sedangkan Antonio (2001) menyatakan bahwa pembiayaan merupakan pemberian fasilitas dana untuk memenuhi kebutuhan pihak-pihak yang membutuhkan pembiayaan.

Dari beberapa definisi diatas, perlu ditegaskan bahwa pengertian pembiayaan yang dilakukan bank syariah sangatlah berbeda dengan istilah kredit yang dilakukan oleh bank syariah. Adapun perbedaannya terletak pada bunga dan bagi hasil. Jika bank konvensional mengharuskan peminjam mengembalikan pinjamannya dengan pemberian bunga kepada bank, sedangkan pembiayaan yang disalurkan bank syariah menggunakan prinsip syariah dan pengembalian pinjamannya dengan bagi hasil berdasarkan kesepakatan antara bank dan peminjam (Ayus \& Aziz, 2009).

Sehingga pembiayaan adalah pemberian modal usaha dimana kesepakatan antara bank dengan nasabah penerima pembiayaan sesuai dengan akad yang disepakati.

\section{Nilai Tukar}

Negara yang menganut perekonomian terbuka, nilai tukar merupakan salah satu variabel terpenting dalam menganalisis suatu masalah. Faisal (2001) menjelaskan bahwa nilai tukar merupakan harga satu mata uang (yang diekspresikan) terhadap mata uang lainnya. Sedangkan Menurut Adiningsih et al. (1998) nilai tukar rupiah merupakan harga mata uang rupiah terhadap mata uang negara lain. Nilai tukar mengalami perubahan nilai yang terus menerus dan relatif tidak stabil karena adanya perubahan permintaan dan penawaran atas suatu nilai mata uang asing pada masing-masing pasar pertukaran mata uang dari waktu ke waktu.

Mankiw (2003) menjelaskan nilai tukar dibagi menjadi dua, yaitu nilai tukar nominal dimana harga mata uang suatu negara dengan negara lainnya dan nilai tukar riil dimana nilai tukar nominal dibagi harga relatif dalam negeri dan luar negeri. Sementara Madura (1993) menjelaskan beberapa faktor yang mempengaruhi pergerakan nilai tukar, yaitu (1) faktor fundamental, berkaitan dengan indikator ekonomi seperti inflasi, tingkat suku bunga, perbedaan relatif pendapatan antarnegara, ekspektasi pasar dan intervensi bank sentral, (2) faktor teknis, berkaitan dengan kondisi penawaran dan permintaan devisa pada saat-saat tertentu. Apabila ada kelebihan permintaan, sementara penawaran tetap, maka harga valuta asing 
akan naik dan begitu pun sebaliknya, (3) sentimen pasar, lebih banyak disebabkan oleh rumor atau berita politik yang bersifat insidentil, sehingga dapat mendorong harga valuta asing naik atau turun secara tajam dalam jangka pendek. Namun, jika berita tersebut sudah berlalu, maka nilai tukar akan kembali normal.

Fraj et al., (2018) menjelaskan juga mengenai fleksibilitas nilai tukar, dimana secara signifikan mengguncang pasar negara berkembang dan mempercepat pertumbuhan ekonomi di negara-negara maju. Lebih lanjut menjelaskan fleksibilitas nilai tukar memerlukan peningkatan tata kelola untuk merangsang pertumbuhan ekonomi di negara-negara berkembang. Sedangkan negara maju, pemerintahan sebaiknya mempercepat pertumbuhan ekonomi jika nilai tukar tidak terlalu fleksibel. Dengan demikian, nilai tukar memainkan peranan penting dalam keputusan pembiayaan di suatu negara.

\section{Inflasi}

Rahardja dan Manurung (2008) menjelaskan bahwa inflasi merupakan kenaikan harga barangbarang yang bersifat umum dan terus-menerus serta dapat diukur dengan indeks harga barang konsumsi dari tahun ke tahun. Hal ini mencerminkan semakin melemahnya daya beli yang diikuti dengan semakin merosotnya nilai mata uang suatu negara.

Pakar ekonomi menggunakan dua konsep untuk mempelajari inflasi, yaitu tingkat harga dimana tingkat rata-rata semua harga-harga dalam sistem ekonomi dan laju inflasi dimana laju kenaikan tingkat harga secara umum. Adapun pengukuran tingkat harga rata-rata menggunakan indeks harga dengan merata-ratakan harga komoditas yang berbeda. Indeks harga yang sering digunakan adalah Indeks Harga Konsumen (IHK) dengan mengukur harga rata-rata barang dan jasa yang dibeli oleh konsumen. IHK menyatakan tingkat harga pada waktu kapan IHK menyatakan tingkat harga pada waktu kapan pun dalam hubungan dengan berapa harga kelompok tertentu yang dikonsumsi oleh rata-rata penduduk dalam periode dasar (Lipsey dan Peter, 1995). Indeks Harga Konsumen ini merupakan indikator yang umum digunakan untuk menggambarkan pergerakan harga dari barang dan jasa yang dikonsumsi masyarakat.

\section{Suku Bunga}

Kebijakan moneter dalam jangka pendek pada dasarnya akan mempengaruhi output dalam jangka pendek, namun akan menyesuaikan diri pada jangka panjang sehingga hanya berpengaruh terhadap harga suatu komoditas (Mishkin, 2004). Kebijakan moneter dengan pendekatan harga menggunakan tingkat suku bunga sebagai sasaran operasionalnya. Adapun indikator yang digunakan sebagai sinyal dalam merespons kebijakan moneter dan sasaran operasional adalah BI Rate. Menurut Bank Indonesia (BI), BI Rate merupakan suku bunga kebijakan yang mencerminkan sikap kebijakan moneter dan ditetapkan oleh BI. BI Rate diimplementasikan melalui SBI (Sertifikat Bank Indonesia) periode satu bulan karena beberapa pertimbangan. Dengan mempertimbangkan faktor-faktor lain dalam perekonomian, BI pada umumnya akan menaikkan BI Rate apabila inflasi ke depan diperkirakan melampaui sasaran yang telah ditetapkan, sebaliknya BI akan menurunkan BI Rate apabila inflasi ke depan diperkirakan berada di bawah sasaran yang telah ditetapkan.

\section{METODOLOGI PENELITIAN}

Data yang digunakan pada penelitian ini seluruhnya menggunakan data sekunder dalam bentuk bulanan yang diperoleh dari Statistik Perbankan Syariah, Bank Indonesia, Badan Pusat Statistik, dan PACIFIC Exchange Rate Service. Data penelitian yang digunakan merupakan data pada pembiayaan Bank Umum Syariah (BUS) dan Unit Usaha Syariah (UUS), nilai tukar (KURS), inflasi (INFL) dan suku bunga (RATE). Data tersebut bersifat time series dengan dimulai dari periode bulan Januari 2010 sampai dengan bulan Desember 2017. 
Tabel 1. Jenis data dan variabel yang digunakan

\begin{tabular}{|l|l|l|}
\hline \multicolumn{1}{|c|}{ Jenis Data } & \multicolumn{1}{c|}{ Variabel } & \multicolumn{1}{c|}{ Sumber } \\
\hline Pembiayaan & Finan & Otoritas Jasa Keuangan \\
\hline Nilai tukar & Kurs & Pacific exchange rate service \\
\hline Inflasi & Infl & Badan Pusat Statistik \\
\hline Suku bunga & Rate & Bank Indonesia \\
\hline
\end{tabular}

Analisis data pada penelitian ini menggunakan pengujian Granger Causality untuk mengetahui apakah suatu variabel endogen dapat dapat diperlakukan sebagai variabel eksogen dan pengaruh antar variabelnya. Jika terdapat dua variable $\mathrm{X}$ dan $\mathrm{Y}$, maka apakah X menyebabkan $\mathrm{Y}$ atau $\mathrm{Y}$ menyebabkan $\mathrm{X}$ atau berlaku keduanya atau tidak ada hubungan keduanya. Variabel $\mathrm{X}$ menyebabkan variabel $\mathrm{Y}$ artinya berapa banyak nilai Y pada periode sekarang dapat dijelaskan oleh nilai Y pada periode sebelumnya dan nilai X pada periode sebelumnya. Granger Causality hanya menguji hubungan diantara variabel dan tidak melakukan estimasi terhadap model. Adapun persamaannya sebagai berikut.

$$
\begin{aligned}
& Y_{t}=\sum_{i=1}^{n} \alpha_{i} Y_{i-1}+\sum_{i=1}^{n} \beta_{i} X_{i-1}+e_{1 t} \\
& X_{t}=\sum_{i=1}^{n} \gamma_{i} X_{i-1}+\sum_{i=1}^{n} \tau_{i} Y_{i-1}+e_{2 t}
\end{aligned}
$$

Dimana :

$\mathrm{Y}_{\mathrm{t}}=$ variabel dependen pertama (pembiayaan, nilai tukar, inflasi dan suku bunga)

$\mathrm{X}_{\mathrm{t}}=$ variabel dependen kedua (pembiayaan, nilai tukar, inflasi dan suku bunga)

Dengan demikian, jika terjadi kausalitas dalam suatu model ekonometrika maka tidak terdapat variabel independen, semua variabel merupakan variabel dependen. Ada atau tidaknya hubungan kausalitas diuji menggunakan uji $\mathrm{F}$ atau dapat dilihat dari nilai probabilitasnya (Widaryono, 2009). Adapun untuk melihat dapat melihat hasil Granger Causality dengan membandingkan F-statistik dengan nilai kritis F-tabel pada tingkat kepercayaan (5 persen) atau dengan membandingkan nilai probabilitasnya dengan tingkat kepercayaan (5 persen). Jika seluruh variabel memiliki nilai F-statistik lebih besar dari nilai F-tabel pada tingkat signifikan, maka kedua variabel tersebut memiliki kausalitas dua arah atau jika nilai probabilitasnya lebih kecil dari tingkat kepercayaan (5 persen), maka kedua variabel tersebut memiliki kausalitas dua arah.

\section{PEMBAHASAN}

Pada pengujian Granger Causality, syarat data yang digunakan adalah data yang bersifat stasioner. Data yang stasioner adalah data yang nilai rata-rata dan variannya tidak mengalami perubahan secara sistematik sepanjang waktu, atau rata-rata dan variannya konstan (Nachrowi dan Usman, 2006). Dari hasil pengujian stasioner data (Tabel 1), dapat dilihat bahwa data keempat variabel sudah stasioner pada first difference karena nilai test critical value (prob.*) lebih kecil dari nilai tstatistic $(0,05)$. Pada penelitian empiris dalam lingkup makroekonomi kebanyakan selalu mengandung non stasioner. Selain itu, variabel yang diujikan juga memiliki trend jika diplotkan. 
Selanjutnya uji kointegrasi yang bertujuan untuk menentukan apakah variabel-variabel yang tidak stasioner terkointegrasi (kondisi dalam keseimbangan jangka panjang) atau tidak. Uji kointegrasi dapat dilakukan dengan menggunakan metode Johansen. Kriteria pengujiannya didasarkan pada trace statistic dan max eigen statistic. Jika nilai trace statistic atau max eigen statistic lebih besar dari pada critical value 5 persen maka dapat diketahui berapa jumlah persamaan yang terkointegrasi dalam sistem. Uji ini untuk mengetahui ada atau tidaknya pengaruh jangka panjang untuk variabel yang akan diteliti. Dari hasil pengujian menggunakan lag 4 diperoleh bahwa dari hasil pengujian kointegrasi dapat dilihat bahwa, nilai trace statistic (60.96792) > critical value (47.85613), begitu juga dengan nilai max eigen statistic (33.29142) > critical value (27.58434), ini berarti bahwa dalam jangka panjang terdapat kointegrasi di dalam model persamaan tersebut.

Tabel 1. Hasil Uji Stasioner

\begin{tabular}{|l|c|c|c|r|}
\hline \multirow{2}{*}{ Variable } & \multicolumn{2}{|c|}{ Level } & \multicolumn{2}{c|}{ First Difference } \\
\cline { 2 - 5 } & t-statistic & Prob. $^{*}$ & t-statistic & Prob. $^{*}$ \\
\hline Finan & -0.387685 & 0.9060 & -10.31270 & 0.0000 \\
\hline Kurs & -0.264049 & 0.9251 & -7.705726 & 0.0000 \\
\hline Infl & -2.659428 & 0.0850 & -7.265420 & 0.0000 \\
\hline Rate & -0.855926 & 0.7980 & -6.491957 & 0.0000 \\
\hline
\end{tabular}

Adapun pengujian Granger Causality dilakukan untuk melihat apakah dua variabel memiliki hubungan kausalitas (bolak balik) atau tidak. Dengan kata lain, apakah satu variabel memiliki hubungan sebab akibat dengan variabel lainnya secara signifikan atau tidak, karena setiap variabel dalam penelitian mempunyai kesempatan untuk menjadi variabel endogen maupun eksogen. Uji kausalitas bivariate pada penelitian ini menggunakan Pairwise Granger Causality Test dan menggunakan taraf nyata 5 persen.

Tabel 2. Hasil Pengujian Kointegrasi

\begin{tabular}{|c|c|c|c|c|}
\hline \multicolumn{5}{|c|}{ Unrestricted Cointegration Rank Test (Trace) } \\
\hline Hypothesized & & Trace & 0.05 & \\
\hline No. of CE(s) & Eigenvalue & Statistic & Critical Value & Prob.** \\
\hline None ${ }^{*}$ & 0.306386 & 60.96792 & 47.85613 & 0.0019 \\
\hline At most 1 & 0.162895 & 27.67650 & 29.79707 & 0.0862 \\
\hline At most 2 & 0.117502 & 11.49616 & 15.49471 & 0.1827 \\
\hline At most 3 & 0.001331 & 0.121242 & 3.841466 & 0.7277 \\
\hline \multicolumn{5}{|c|}{ Unrestricted Cointegration Rank Test (Maximum Eigenvalue) } \\
\hline Hypothesized & Eigenvalue & Max-Eigen & 0.05 & \\
\hline No. of CE(s) & 0.306386 & 33.29142 & 27.58434 & 0.0083 \\
\hline None $*$ & 0.162895 & 16.18034 & 21.13162 & 0.2145 \\
\hline At most 1 & 0.117502 & 11.37491 & 14.26460 & 0.1364 \\
\hline At most 2 & 0.001331 & 0.121242 & 3.841466 & 0.7277 \\
\hline At most 3 &
\end{tabular}

Dengan menggunakan lag 4 yang terdapat pada tabel 3 hasil pengujian granger causality variabel pembiayaan (FINAN) secara statistik signifikan mempengaruhi nilai tukar (KURS) dan begitu pula sebaliknya variabel nilai tukar (KURS) secara statistik signifikan memengaruhi variabel inflasi (INF) 
yang dibuktikan dengan nilai prob masing-masing kurang dari 5 persen, yaitu 0,008 dan 0,0481. Sehingga dapat disimpulkan bahwa terjadi hubungan kausalitas dua arah antara variabel pembiayaan dengan variabel nilai tukar. Mankiw (2003) menyatakan jika nilai tukar riil tinggi, barang-barang dari luar negeri relatif lebih murah, sedangkan barang-barang dalam negeri lebih mahal begitu sebaliknya. Peningkatan ketersediaan informasi tentang tujuan kebijakan moneter akan menurunkan volatilitas nilai tukar (Eichler \& Littke, 2018). Rifai et al (2017) menambahkan jika nilai tukar rupiah terdepresiasi, maka barang produksi atau jasa yang dihasilkan negara itu menjadi lebih mahal. Akibatnya, permintaan barang atau jasa akan menurun dan menyebabkan terjadinya substitusi yang menekan permintaan. Saat permintaan menurun, produsen akan menurunkan pasokan dan memiliki keseimbangan baru. Pengurangan pasokan dilakukan dengan mengurangi produksi menyebabkan ekonomi mengalami perlambatan sehingga kebutuhan dana untuk modal kerja maupun investasi berkurang, yang pada akhirnya bank mengalami kesulitan dalam menyalurkan pembiayaan begitu sebaliknya (Cahyono, 2009).

Tabel 3. Hasil Pengujian Granger Causality

\begin{tabular}{|c|c|c|c|}
\hline Null Hypothesis: & Obs & F-Statistic & Prob. \\
\hline KURS does not Granger Cause FINAN & 92 & 3.70458 & 0.0080 \\
\hline \multicolumn{2}{|l|}{ FINAN does not Granger Cause KURS } & 2.50789 & 0.0481 \\
\hline INFL does not Granger Cause FINAN & 92 & 2.20538 & 0.0754 \\
\hline \multicolumn{2}{|l|}{ FINAN does not Granger Cause INFL } & 0.39681 & 0.8104 \\
\hline RATE does not Granger Cause FINAN & 92 & 1.65950 & 0.1672 \\
\hline \multicolumn{2}{|l|}{ FINAN does not Granger Cause RATE } & 0.78335 & 0.5392 \\
\hline INFL does not Granger Cause KURS & 92 & 1.12307 & 0.3513 \\
\hline \multicolumn{2}{|l|}{ KURS does not Granger Cause INFL } & 1.48678 & 0.2136 \\
\hline RATE does not Granger Cause KURS & 92 & 2.03099 & 0.0975 \\
\hline \multicolumn{2}{|l|}{ KURS does not Granger Cause RATE } & 0.54151 & 0.7057 \\
\hline RATE does not Granger Cause INFL & 92 & 0.86076 & 0.4911 \\
\hline \multicolumn{2}{|l|}{ INFL does not Granger Cause RATE } & 4.18310 & 0.0039 \\
\hline
\end{tabular}

Variabel pembiayaan (FINAN) secara statistik tidak mempengaruhi inflasi (INFL) dan begitu pula sebaliknya variabel inflasi (INFL) secara statistik tidak mempengaruhi variabel pembiayaan (FINAN) yang dibuktikan dengan nilai prob masing-masing lebih dari 5 persen, yaitu 0,0754 dan 0,8104. Sehingga dapat disimpulkan bahwa tidak terjadi hubungan kausalitas antara variabel pembiayaan dengan variabel inflasi. Menurut Karim (2017), inflasi mencerminkan stabilitas ekonomi yang secara teori inflasi dapat melemahkan semangat menabung masyarakat, meningkatkan kecenderungan berbelanja dan mengarahkan investasi pada hal-hal yang tidak produktif (Karim, 2015). Pada masa inflasi, masyarakat cederung menarik dana lebih banyak dari simpanannya untuk memenuhi kebutuhannya, sehingga dana yang dihimpun perbankan akan mengalami penurunan, berakibat pada penurunan penyaluran pembiayaan perbankan (Muttaqiena, 2013). Pembiayaan juga bersifat prosiklik, yaitu kondisi dimana pemerintah meningkatkan belanja ketika perekonomian sedang baik dan menurunkannya ketika kondisi perekonomian sedang buruk (resesi) karena probabilitas default lebih tinggi (Yao el al., 2017)

Variabel pembiayaan (FINAN) secara statistik tidak mempengaruhi suku bunga (RATE) dan begitu pula sebaliknya variabel suku bunga (RATE) secara statistik tidak mempengaruhi variabel pembiayaan (FINAN) yang dibuktikan dengan nilai prob masing-masing lebih dari 5 persen, yaitu 0,1672 dan 0,5392. Sehingga dapat disimpulkan bahwa tidak terjadi hubungan kausalitas antara variabel pembiayaan dengan variabel inflasi. Dalam menyalurkan pembiayaan, bank syariah menggunakan 
sejumlah akad dan sistem bagi hasil dalam setiap transaksinya. Ketersediaan kredit memungkinkan perbankan untuk mengurangi konsumsi secara signifikan, perubahan harga menjadi fleksibel dan likuiditas menjadi rendah (Dotsey \& Quintana, 2016). Karena mengurangi biaya kredit juga efektif dalam melakukan kebijakan moneter. Selain itu juga, perbankan akan memastikan sumber daya mereka untuk jangka panjang selama periode risiko yang tinggi dengan meningkatkan secara signifikan simpanannya. Perbankan juga cenderung mengutamakan perusahaan dari pada rumah tangga (Papadamou \& Markopoulos, 2018). Di Eropa, kebijakan suku bunga cenderung menurun selama hampir satu dekade dari sekarang. Campmas (2018) menyatakan bahwa bahwa instrumen utama kebijakan moneter akan memberikan dampak negatif terhadap pendapatan bank. Ketika melakukan kebijakan dengan menurunkan suku bunga, pengaruh dari Net Interest Margin masih positif, sementara pengaruh pada profitabilitas secara keseluruhan menjadi negatif. Walaupun demikian, bank-bank Eropa berhasil meningkatkan profitabilitas mereka meskipun mengurangi pendapatan bunga bersih mereka.

Variabel nilai tukar (KURS) secara statistik tidak mempengaruhi inflasi (INFL) dan begitu pula sebaliknya variabel inflasi (INFL) secara statistik tidak mempengaruhi variabel nilai tukar (KURS) yang dibuktikan dengan nilai prob masing-masing lebih dari 5 persen, yaitu 0,3513 dan 0,2136. Sehingga dapat disimpulkan bahwa tidak terjadi hubungan kausalitas antara variabel nilai tukar dengan variabel inflasi. Tingginya inflasi menyebabkan kenaikan harga. Dengan harga yang semakin tinggi, otomatis nilai tukar rupiah juga terdampak. Pelemahan nilai tukar rupiah berakibat pada naiknya harga-harga barang di pasaran. Campur tangan bank sentral mampu menetralkan pengaruh buruk inflasi yang disebabkan oleh nilai tukar sehingga dapat berkontribusi terhadap stabilitas harga-harga komoditas di negara berkembang (Mendonca \& Tiberto, 2017). Fleksibilitas nilai tukar dan inflasi dapat menimbulkan risiko ketidakpastian yang tinggi sehingga diperlukan pengelolaan nilai tukar yang dapat mengatur pergerakan inflasi (Buffie $e t$ al., 2018). Penelitian lain mengemukakan bahwa perubahan nilai tukar ini tidak memengaruhi volume ekspor dan penguatan nilai tukar juga tidak mempengaruhi harga saham dan harga barang untuk industri (Thorbecke \& Kato, 2018).

Variabel nilai tukar (KURS) secara statistik tidak mempengaruhi suku bunga (RATE) dan begitu pula sebaliknya variabel suku bunga (RATE) secara statistik tidak mempengaruhi variabel nilai tukar (KURS) yang dibuktikan dengan nilai prob masing-masing lebih dari 5 persen, yaitu 0,0975 dan 0,7057. Sehingga dapat disimpulkan bahwa tidak terjadi hubungan kausalitas antara variabel nilai tukar dengan variabel suku bunga. Setiap kenaikan suku bunga akan berdampak besar bagi pasar uang serta pasar modal, dimana investor akan menarik dananya dan melakukan capital out flow memulangkan dananya untuk ditanamkan dalam bentuk simpanan atau deposito (Murtadho, 2016). Perubahan suku bunga yang dipengaruhi kebijakan akan mempengaruhi keuntungan komposisi neraca suatu perbankan bank (English, et al., 2008)

Variabel inflasi (INFL) secara statistik tidak mempengaruhi suku bunga (RATE), namun variabel suku bunga (RATE) secara statistik mempengaruhi variabel inflasi (INFL) yang dibuktikan dengan nilai prob masing-masing lebih dari dan kurang dari 5 persen, yaitu 0,4911 dan 0,0039. Sehingga dapat disimpulkan bahwa terjadi hubungan kausalitas satu arah antara variabel suku bunga dengan variabel inflasi. Di Eropa, krisis keuangan telah ditandai oleh fragmentasi dalam transmisi kebijakan moneter, sebagaimana tercermin pada perpindahan dalam suku bunga pinjaman bank kepada perusahaanperusahaan (Holton \& D'Acri, 2018). Audzei dan Brazdik (2017) menambahkan nilai tukar riil khususnya di Eropa timur dan tengah merupakan sumber dari perubahan harga yang menunjukan fluktuasi pasar dalam satu periode tertentu (volatilitas). 
V. KESIMPULAN

Berdasarkan hasil pengujian Granger Causality dan pembahasan diatas dapat disimpulkan bahwa terjadi hubungan kausalitas dua arah terjadi antara variabel pembiayaan dan variabel inflasi dimana variabel pembiayaan dan variabel inflasi saling mempengaruhi, sedangkan variabel suku bunga dan variabel inflasi terjadi hubungan kausalitas satu arah, dimana suku bunga mempengaruhi inflasi sedangkan inflasi tidak mempengaruhi suku bunga. Adapun variabel pembiayaan dan variabel inflasi, variabel pembiayaan dan variabel suku bunga, variabel nilai tukar dan variabel inflasi serta variabel nilai tukar dan variabel suku bunga tidak terjadi hubungan kausalitas satu arah maupun dua arah.

\section{DAFTAR PUSTAKA}

Adiningsih, S., Harianto, F., \& Sudomo, S. 1998. Perangkat Analisis dan Teknik Analisis Investasi di Pasar Modal Indonesia. Jakarta : Bursa Efek Jakarta.

Alandejania, M., \& Asutay, M. 2017. Non Performing Loans in the GCC Banking Sectors: Does the Islamic Finance Matter?. Journal Research in International Business and Finance, 42, 832-854.

Antonio, M. S. 2001. Bank Syariah Dari Teori ke Praktik. Gema Insani Press: Jakarta.

Ayus, A. Y., \& Aziz, A. 2009. Manajemen Operasional Bank Syariah. Cirebon : STAIN Press.

Ardana, Y., \& Irviani, R. 2017. Kondisi Makroekonomi Terhadap Tingkat Pembiayaan Bermasalah Bank Umum Syariah di Indonesia (Periode Januari 2009-Desember 2015 dengan model ECM). Jurnal Media Trend, 12(1), 1-11.

Audzei, V., \& Brázdik, F. 2018. Exchange Rate Dynamics and Their Effect on Macroeconomic Volatility in Selected CEE Countries. Journal Economic Systems, 42(4), 584-596.

Buffie, E. F., Airaudo, M., \& Zanna, F. 2018. Inflation Targeting and Exchange Rate Management in Less Developed Countries. Journal of International Money and Finance, 81, 159-184.

Cahyono, A. 2009. Pengaruh Indikator Makroekonomi terhadap Dana Pihak Ketiga dan Pembiayaan Bank Syariah Mandiri. Tesis. Pascasarjana Fakultas Ekonomi Universitas Indonesia.

Campmas, A. 2018. How do European banks portray the effect of policy interest rates and prudential behavior on profitability?. Journal Research in International Business and Finance, 1-44.

Dotsey, M., \& Quintana, P. A. G. 2016. Interest Rates and Prices in an Inventory Model of Money With Credit. Journal of Monetary Economics, 83, 71-89.

Eichler, S., \& Littke, H. C. N. 2018. Central Bank Transparency and The Volatility of Exchange Rates. Journal of International Money and Finance, 89, 23-49.

English, W, B., Heuvel, S. J. V. D., \& Zakrajsek, E. 2008. Interest Rate Risk and Bank Equity Valuations. Journal of Monetary Economics, 98, 80-97.

Faisal, M. 2001. Manajemen Keuangan Internasional. Jakarta : Salemba Empat.

Forbes, K., Hjortsoe, I., \& Nenova, T. 2018. The Shocks Matter: Improving Our Estimates of Exchange Rate Pass-Through. Journal of International Economics, 114, 255-275.

Fraj, S. H., Hamdaoui, M., \& Maktouf, S. 2018. Governance and Economic Growth: The Role of The Exchange Rate Regime. Journal International Economics, 156, 326-364.

Gheeraerta, L., \& Weill, L. 2017. Does Islamic Banking Development Favor Macroeconomic Efficiency? Evidence on the Islamic finance-Growth nexus. Journal Economic Modelling, 47, 32-39.

Holton, S., \& D'Acri, C. R. 2018. Interest Rate Pass-Through Since The Euro Area Crisis. Journal of Banking \& Finance, 96, 277-291.

Ichsan, N., \& Akhiroh, M. 2018. Analisis Pengaruh Ekonomi Makro dan Stabilitas Perbankan Syariah Terhadap Pembiayaan Produktif dan Konsumtif Pada Perbankan Syariah di Indonesia Periode Januari 2010 - Maret 2017. Jurnal Akses Ekonomi dan Bisnis, 12(23), 68-83. 
Karim, A. 2015. Ekonomi Makro Islam Edisi Ketiga. Jakarta: PT Raja Grafindo Persada.

Lipsey, R. G., \& Peter, D. S. 1995. Pengantar Makroekonomi. Jakarta : Binarupa Aksara.

Mankiw, G. N. 2003. Pengantar Ekonomi Edisi Kedua. Jakarta: Erlangga.

Madura, J. 1993. Financial Management. Florida : University Express.

Mendonça, H. F. D., \& Tiberto, B. P. 2017. Effect of Credibility and Exchange Rate Pass-Through on Inflation: An Assessment for Developing Countries. Journal International Review of Economics \& Finance, 50, 196-244.

Mishkin, F. S. 2004. The Economics of Money, Banking and Financial Markets. Massachusetts : Addison Wesley.

Murthado, M. 2016. Pengaruh Suku Bunga Terhadap Nilai Tukar Serta Pengaruhnya Terhadap Indeks Harga Saham (Studi Kasus Indonesia, China dan Australia). Jurnal Manajemen Kinerja, 2(2).

Nachrowi, D., \& Usman, H. 2006. Pendekatan Populer dan Praktis Ekonometrika Untuk Analisis Ekonomi dan Keuangan. Depok : Lembaga Penerbit Fakultas Ekonomi Universitas Indonesia.

Naufal, G. N., Fadilah, S., \& Helliana. 2017. Pengaruh Dana Pihak Ketiga, Rasio Keuangan Bank, Inflasi dan BI (Studi pada Bank Umum Syariah yang Terdaftar di Bank Indonesia). Jurnal Prosiding Akuntansi, 3(2), 391-402.

Papadamou, S., \& Markopoulos, T. 2018. Interest Rate Pass Through in a Markov-Switching Vector Autoregression Model: Evidence from Greek Retail Bank Interest Rates. The Journal of Economic Asymmetries, 17, 48-60.

Rahardja, P., \& Manurung, M. 2008. Teori Ekonomi Makro ; Suatu Pengantar. Ed- ke 4. Depok : Lembaga Penerbit Fakultas Ekonomi Universitas Indonesia.

Rifai, S. A., Susanti, H., \& Setyaningrum, A. 2017. Analisis Pengaruh Kurs Rupiah, Laju Inflasi, Jumlah Uang Beredar dan Pertumbuhan Ekspor terhadap Total Pembiayaan Perbankan Syariah dengan Dana Pihak Ketiga sebagai Variabel Moderating. Jurnal Ekonomi dan Perbankan Syariah, 8(1), 13-27.

Thorbecke, W., \& Kato, A. 2018. Exchange Rates and the Swiss Economy. Journal of Policy Modeling, 40(6), 1182-1199.

Widarjono, A. 2009. Ekonometrika Pengantar dan Aplikasinya. Ekonosia : Yogyakarta.

Yao, Z., Gua, D., \& Chen, Y. 2017. Rating Deflation Versus Inflation: On Procyclical Credit Ratings. Pacific Basin Finance Journal, 41, 46-64. 